\title{
KLASIFIKASI TUTUPAN LAHAN MENGGUNAKAN CITRA LANDSAT 8 OPERATIONAL LAND IMAGER (OLI) DI KECAMATAN PANGANDARAN
}

\author{
Roihan Muhammad Derajat*, Yesi Sopariah, Syifa Aprilianti, Aditya Candra Taruna, \\ Hangga Aria Rahmawan Tisna, Riki Ridwana, Dede Sugandi \\ Pendidikan Geografi, FPIPS, Universitas Pendidikan Indonesia, Bandung, Indonesia \\ rmderajat777@upi.edu
}

\begin{tabular}{ll}
\hline \multicolumn{2}{c}{ INFO ARTIKEL } \\
\hline \multicolumn{2}{l}{ Riwayat Artikel $:$} \\
\begin{tabular}{ll} 
Dikirim & $: 31-12-2019$ \\
Disetujui & $: 25-01-2020$ \\
Diterbitkan & $: 31-01-2020$ \\
\hline
\end{tabular} \\
\hline
\end{tabular}

\section{Kata Kunci :}

Citra Landsat, Perubahan

Penggunaan Lahan,

Klasifikasi Tidak

Terbimbing
Satellite image data used to review the classification of land cover in Pangandaran District Tourism District Pangandaran District. The study was conducted in several ways, namely image pre-processing, visual image interpretation, image class classification, groundchek and accuracy test. The method used in this study is the unsupervised classification method (unsupervised classification) IsoData and K-meas. This study aims to classify land cover in Pangandaran districts using Landsat 8 OLI (Operational Land Imager) satellite imagery from the latest recording results. The map of land classification results in this study has an accuracy level of $86.67 \%$ and has met the requirements set byUSGS. The land cover classes contained in the study area based on imagery are natural / semi-natural vegetation coverage, mangrove forests, non-residential buildings, and mixed residential buildings. The benefits of the maps of land cover results are for spatial analysis in the area of regional planning or development.

Data citra satelit digunakan untuk mendeteksi klasifikasi penutupan lahan di Kawasan Wisata Kecamatan Pangandaran Kabupaten Pangandaran. Penelitian dilakukan dengan beberapa tahap, yaitu pra-pengolahan citra, interpretasi visual citra, membuat penciri kelas klasifikasi citra, groundchek, dan uji akurasi. Metode yang digunakan dalam penelitian ini yaitu metode klasifikasi tidak terbimbing (unsupervised classification) IsoData dan Kmeans. Penelitian ini bertujuan untuk melakukan klasifikasi tutupan lahan di Kecamatan Pangandaran menggunakan citra satelit Landsat 8 OLI (Operational Land Imager) hasil perekaman terakhir. Peta hasil klasifikasi lahan dalam penelitian ini memiliki tingkat akurasi ketelitian $86.67 \%$ dan telah memenuhi syarat yang sudah ditentukan USGS. Kelas-kelas penutup lahan yang terdapat pada wilayah penelitian berdasarkan citra adalah liputan vegetasi alami/semi alami lain, hutan mangrove, bangunan bukan pemukiman, dan bangunan pemukiman campuran. Manfaat peta hasil klasifikasi tutupan lahan tersebut adalah untuk analisis spasial dalam bidang perencanaan wilayah atau pembangunan.

\section{PENDAHULUAN}

Pangandaran merupakan salah satu daerah tujuan wisata yang terletak di pantai Selatan Jawa Barat. Menurut Van Bemmelen (1968), Pangandaran secara fisiografis termasuk ke dalam Southern Mountains Zone (Zona
Pegunungan Selatan) dengan karakteristik utama merupakan pantai yang sedang mengalami pengangkatan. Karakteristik tersebut memberikan konsekuensi terhadap daerah Pangandaran sebagai berikut: pertama, dasar pantai yang terangkat akan 
mengikutsertakan komponen yang dimilikinya, seperti batu karang, gua, tanaman laut dan sebagainya menjadi bagian dari keberadaan pantai tersebut. Kedua, jika batuannya mengandung kapur, daerah tersebut merupakan daerah karst yang memiliki sifat mudah larut dalam air, lapisan tanah yang tipis, dan sungai bawah tanah, sehingga rentan terhadap erosi dan abrasi (Hayati, 2010).

Daerah pangandaran ini sangat jelas merupakan wilayah yang potensial dan mendukung terhadap aktifitas pariwisata, meskipun bersamaan dengan potensi tersebut terdapat pula ancaman-ancaman yang senantiasa terjadi kapan saja. Oleh karena itu peta tutupan penggunaan lahan menjadi salah satu faktor penting dalam menunjang aktifitas ekonomi, pariwisata dan perencanaan wilayah di kawasan tersebut. Potensi objek dan daya tarik di Propinsi Jawa Barat sangat beragam dan tersebar di kabupaten/kota di Jawa Barat (Hidayat, 2011).

Tutupan lahan adalah kenampakan material fisik permukaan bumi. Tutupan lahan dapat menggambarkan keterkaitan antara proses alami dan proses sosial. Tutupan lahan dapat menyediakan informasi yang sangat penting untuk keperluan pemodelan serta untuk memahami fenomena alam yang terjadi di permukaan bumi (Liang, 2008. Dalam Sampurno, 2016). Informasi tutupan lahan yang akurat merupakan salah satu faktor penentu dalam meningkatkan kinerja dari model-model ekosistem, hidrologi, dan atmosfer (Sampurno, 2016).

Mencari keakuratan suatu data tidak mudah, harus melalui berbagai persiapan panjang mulai dari pra-pengolahan citra, interpretasi visual citra, membuat penciri kelas klasifikasi citra, dan uji akurasi. dengan langsung turun kelapangan, tentu setelah turun ke lapangan langkah-langkah yang harus di ambil ialah mengidentifikasi kesesuaian objek dilapangan dengan peta (Sampurno, 2016).

\section{METODE PENELITIAN}

\section{Waktu dan Tempat Penelitian}

Dilakukan di kawasan wisata Kecamatan Pangandaran, Kabupaten Pangandaran, Provinsi Jawa Barat, pada 31 November - 1 Desember 2019.

\section{Alat dan Bahan}

Alat yang digunakan untuk menunjang kegiatan di lapangan adalah kompas, aplikasi avenza map, ENVI 5.3, dan ArcGis yang terpasang dalam perangkat computer. Bahan yang diperlukan untuk menunjang aktifitas penelitian adalah data citra Landsat 8 OLI, data administrasi kecamatan pangandaran dan peta Rupa Bumi Indonesia (RBI) sebagai alat bantu interpretasi citra, dan parametee Klasifikasi Penutup Lahan berdasarkan SNI 2014 data shp sungai, jalan, kecamatan dan kabupaten pangandaran.

\section{Metode Klasifikasi Citra Tutupan Lahan}

Klasifikasi citra merupakan suatu proses penyusunan, atau pengelompokan semua pixel (yang terdapat di dalam band citra yang bersangkutan) ke dalam beberapa kelas berdasarkan suatu kriteria atau kategori objek, sehingga menghasilkan "peta tematik" dalam bentuk raster. Di dalam pengklasifikasian citra digital, secara umum dikenal dengan dua kelompook metode tak terbimbing (unsupervised classification) dan terbimbing (supervised classification). klasifikasi citra digital bertujuan untuk identifikasi kenampakan spektral obyek (Muttaqin, 2011). Keunggulan unsupervised classification adalah kesalahan operator diminimalisir dan unique classes dianggap sebagai distinct units. Kekurangannya adalah korespondensi yang tidak jelas terhadap informational classes, kontrol yang terbatas terhadap classes, dan spectral classes tidak konstan. Penelitian ini menggunakan dua jenis unsupervised classification yaitu K-Means dan IsoData (Septiani, 2019). Klasifikasi tidak terbimbing merupakan proses pengelompokkan pixel-pixel pada citra menjadi beberapa kelas menggunakan analisa cluster (cluster analysis) (Wibowo, 2013).

Secara umum penelitian dilakukan dengan beberapa tahap, yaitu: pra-pengolahan citra, , interpretasi visual citra, membuat penciri kelas klasifikasi citra, groundchek dan uji akurasi. Tahap pra-pengolahan yang dilakukan adalah penyiapan alat dan bahan. Citra Landsat 8 OLI untuk area penelitian didownload dari website United States Geological Survey (USGS) (http://earthexplorer.usgs.gov/). Data tersebut diolah menggunakan ENVI 5.3 untuk mengklasifikasikannya ke dalam IsoData dan 
K-Means, kemudian diolah menjadi peta dengan menggunakan software ArcGis dan penentuan sebaran titik plot sampel untuk groundchek. Berikut adalah peta sebaran titik plot yang akan di groundchek, masing-masing plot berjarak 300 meter di lapangan.

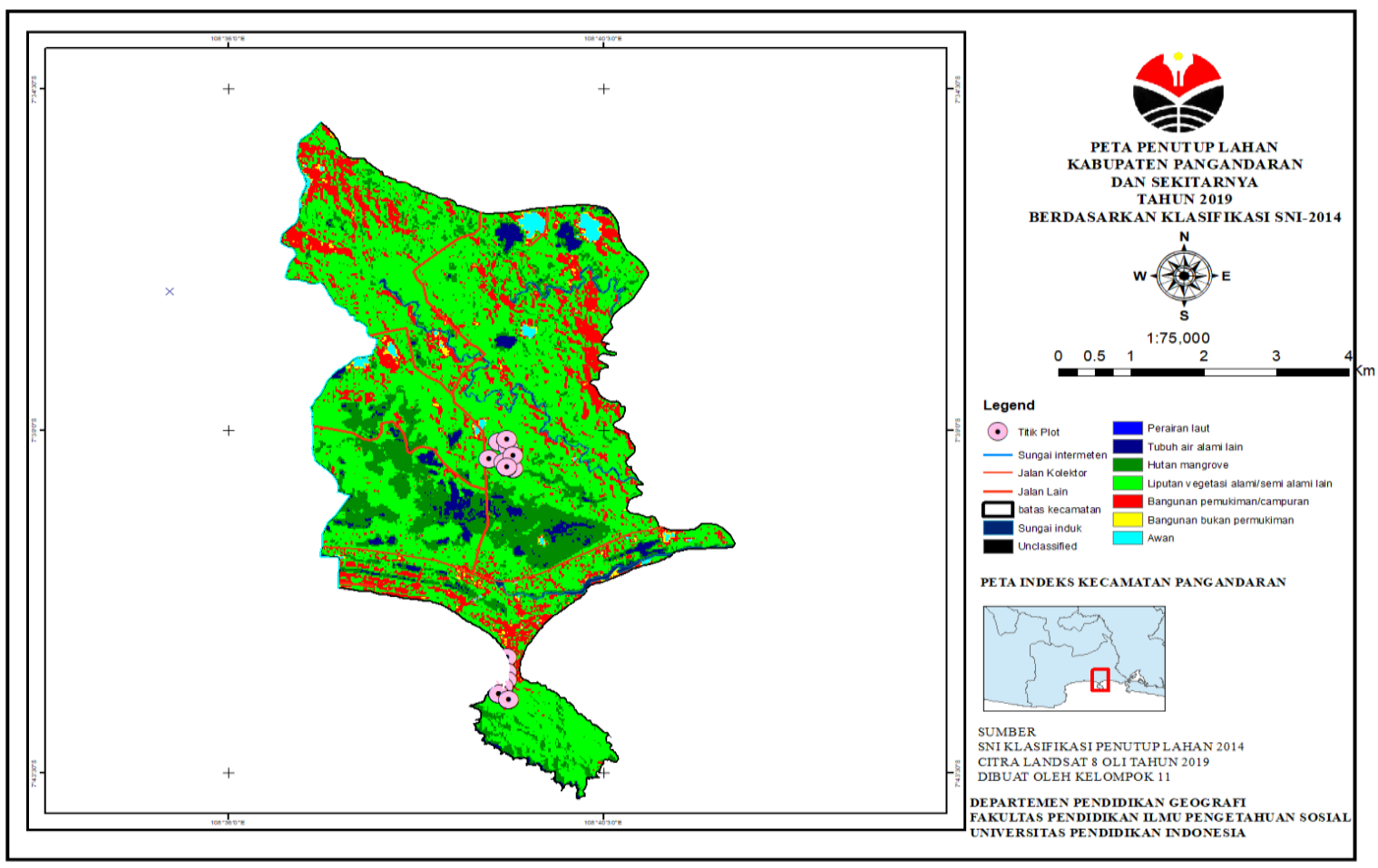

Gambar 1. Peta Sebaran Plot Titik Sampel

Interpretasi visual citra dilakukan berdasarkan pada pengenalan ciri obyek secara spasial. Karakteristik obyek dapat dikenali berdasarkan unsur-unsur interpretasi seperti warna, bentuk, ukuran, pola, tekstur, bayangan, letak dan asosiasi kenampakan obyek, serta tambahan data dari penggunaan peta RBI. Penciri kelas diperlukan dalam proses klasifikasi. Penciri kelas merupakan satu set data yang diperoleh dari suatu training area, feature space, atau cluster. Training area atau area contoh digunakan untuk mendapatkan penciri kelas. Sekelompok training area mewakili satu kelas tutupan lahan, misalnya hutan, sawah, badan air, dan kawasan terbangun (Sampurno, 2016).

Menurut Pahleviannur

Groundchek dan uji akurasi merupakan suatu proses memvalidasi hasil analisis digital dengan pengukuran yang dilakukan di lapangan. Salah satu cara yang dapat dilakukan untuk uji akurasi adalah dengan menggunakan matriks kesalahan. Tabel matriks kesalahan tidak hanya digunakan untuk memperoleh akurasi seluruh kategori, tetapi juga akurasi tiap kategori. United States Geological Survey (USGS) telah menetapkan tingkat ketelitian klasifikasi atau interpretasi minimum dengan menggunakan penginderaan jauh yaitu $85 \%$.

\section{Uji Akurasi}

Menurut Sampurno (2016) uji akurasi digunakan untuk melihat tingkat kesalahan yang terjadi pada klasifikasi area sehingga dapat ditentukan besarnya persentase ketelitian pemetaan. Akurasi ketelitian pemetaan dilakukan dengan membuat matrik kontingensi atau matrik kesalahan (confusion matrix) seperti yang disajikan pada Tabel 1 .

Angka dalam matriks diagonal merupakan hasil klasifikasi dan data lapangan yang benar atau sesuai. Apabila angka-angka pada diagonal utama tersebut dijumlahkan dan kemudian dibagi dengan jumlah sampel maka akan didapatkan akurasi seluruh kategori. Saat ini akurasi yang dianjurkan adalah akurasi kappa, karena overral accuracy secara umum masih over estimate. Akurasi kappa ini sering juga disebut dengan indeks kappa (Jaya, 2013). 
Tabel 1. Contoh Matriks kesalahan (confusion matrix).

\begin{tabular}{|c|c|c|c|}
\hline $\begin{array}{l}\text { Data } \\
\text { Referen } \\
\text { si }\end{array}$ & $\begin{array}{l}\text { Diklasifikasi } \\
\text { kan ke dalam } \\
\text { kelas (Data } \\
\text { kelas di peta) }\end{array}$ & $\begin{array}{l}\text { Jumla } \\
\text { h }\end{array}$ & $\begin{array}{l}\text { Produce } \\
r \text { 's } \\
\text { accuracy }\end{array}$ \\
\hline & $\begin{array}{lll}\text { A } & \text { B } & \text { C } \\
\text { D } & & \end{array}$ & & \\
\hline A & $\mathrm{X}_{\mathrm{ii}}$ & $\mathrm{X}_{\mathrm{i}+}$ & $\mathrm{X}_{\mathrm{ii}} / \mathrm{X}_{\mathrm{i}+}$ \\
\hline B & & & \\
\hline $\mathrm{C}$ & & & \\
\hline $\mathrm{D}$ & $\mathrm{X}_{\mathrm{ii}}$ & & \\
\hline $\begin{array}{l}\text { Total } \\
\text { Kolom }\end{array}$ & $\mathrm{X}_{\mathrm{i}+}$ & & \\
\hline $\begin{array}{l}\text { User's } \\
\text { Accura } \\
\text { cy }\end{array}$ & $\begin{array}{l}\mathrm{X}_{\mathrm{ii} /} \\
\mathrm{X}_{\mathrm{i}+}\end{array}$ & & \\
\hline
\end{tabular}

Keterangan:

Xii $=$ nilai diagonal matriks kontingensi baris ke-i dan kolom ke-i

$\mathrm{Xi}+=$ jumlah piksel dalam baris ke- $\mathrm{i}$

$\mathrm{X}+\mathrm{i}=$ jumlah piksel dalam kolom ke- $\mathrm{i}$

Secara matematis akurasi kappa disajikan sebagai berikut:

$$
\operatorname{Kappa}(\mathrm{k})=\frac{\mathrm{N} \sum_{i}^{r} \mathrm{X}_{\mathrm{ii}}-\sum_{i}^{r} \mathrm{X}_{\mathrm{i}+} \mathrm{X}_{+\mathrm{i}}}{\mathrm{N}^{2}-\sum_{i}^{r} \mathrm{X}_{\mathrm{i}+} \mathrm{X}_{+\mathrm{i}}} \times 100 \%
$$

Keterangan :

$\mathrm{N}=$ banyaknya piksel dalam contoh

$\mathrm{X}=$ nilai diagonal dari matriks kontingensi baris ke-i dan Kolom ke-i

$\mathrm{Xii}=$ jumlah piksel dalam baris ke-i

$\mathrm{Xi}+=$ jumlah piksel dalam kolom ke-i

\section{HASIL DAN PEMBAHASAN \\ Interpretasi Citra}

Berdasarkan citra landsat 8 OLI yang diolah menggunakan metode (unsupervised classification) IsoData dan K-means, dan software ArcGis. Sudah diperoleh 2 peta penutupan lahan dengan objek visual yang teridentifikasi sebanyak 7 objek, yaitu 4 objek hasil unsupervised IsoData, dan 2 objek hasil unsupervised K-Means, kenampakan jenisjenis tutupan lahan ditampilkan dengan warna yang berbeda-beda yaitu sebagai berikut:

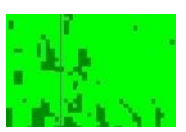

a)

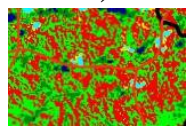

d)

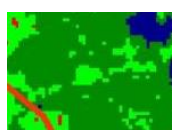

b)

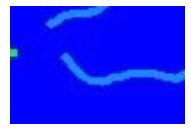

e)

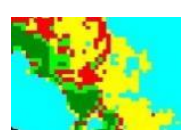

c)

f)

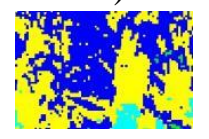

Gambar 2. Interpretasi peta hasil pengolahan Kenampakan Objek Permukaan Bumi.

Berdasarkan gambar diatas, gambar a) penulis interpretasikan sebagai objek liputan vegetasi alami/semi alami lain. Gambar b) diinterpretasikan sebagai objek hutan mangrove. Gambar c) diinterpretasikan sebagai objek bangunan bukan pemukiman. Gambar d) diinterpretasikan sebagai objek bangunan pemukiman campuran. Gambar e) diinterpretasikan sebagai objek liputan vegetaasi alami/semi alami lain. Gambar f) diinterpretasikan sebagai objek bangunan pemukiman campuran. Proses interpretasi tersebut didasari oleh rona/warna, bentuk, ukuran, tekstur, pola, bayangan, situs, dan asosiasi.

\section{Klasifikasi Tutupan Lahan data OLI di Kecamatan Pangandaran}

Peta hasil klasifikasi tutupan lahan data OLI menggunakan IsoData dan K-Means ditunjukkan pada Gambar 2 dan Gambar 3. Secara visual, setiap kelas dapat diidentifikasi menggunakan pengklasifikasi unsupervised IsoData dan K-Means. 


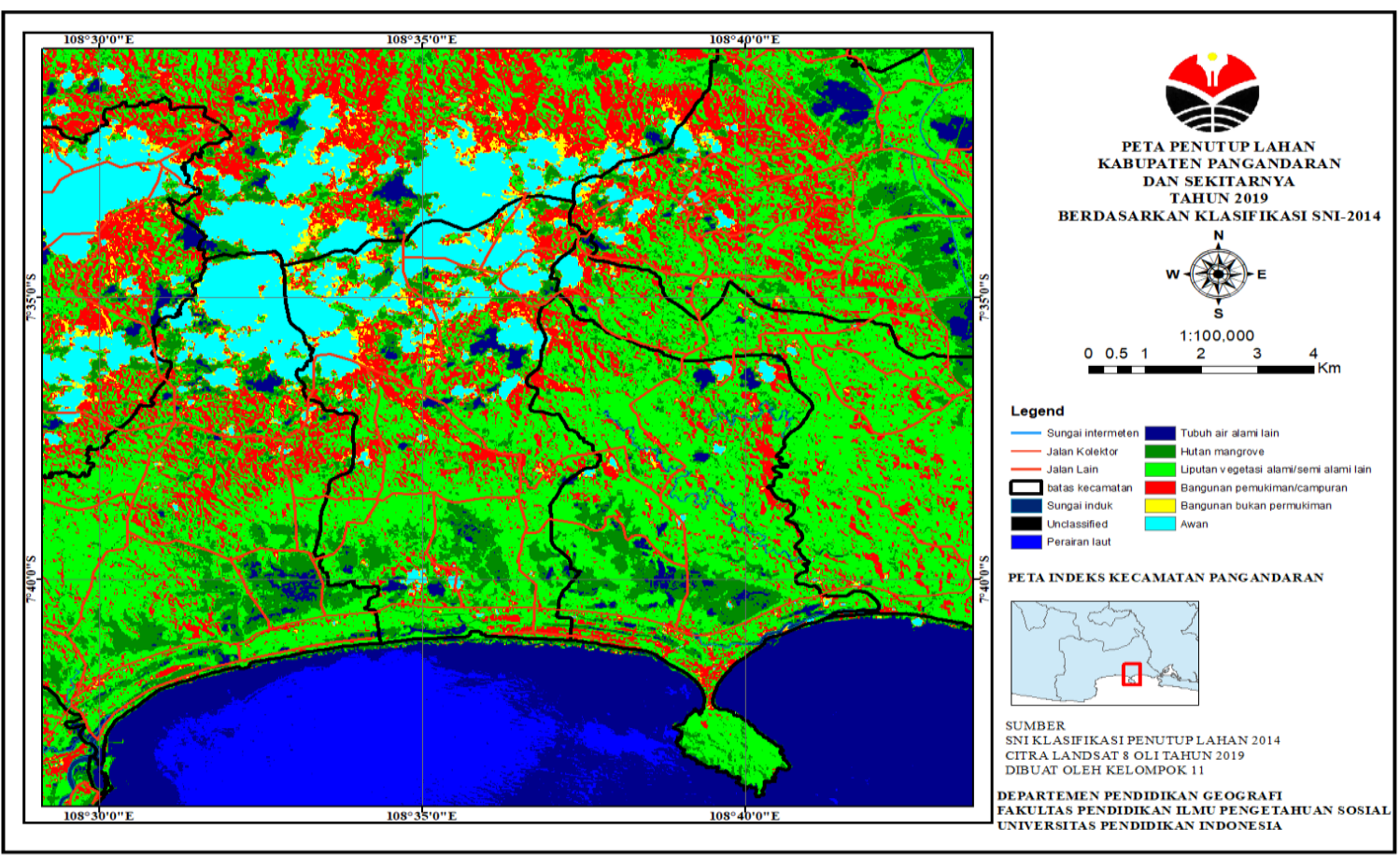

Gambar 3. Peta Penutup Lahan Kabupaten Pangandaran Tahun 2019 Berdasarkan Klasifikasi SNI2014 Menggunakan Metode Unsupervised classification IsoData.

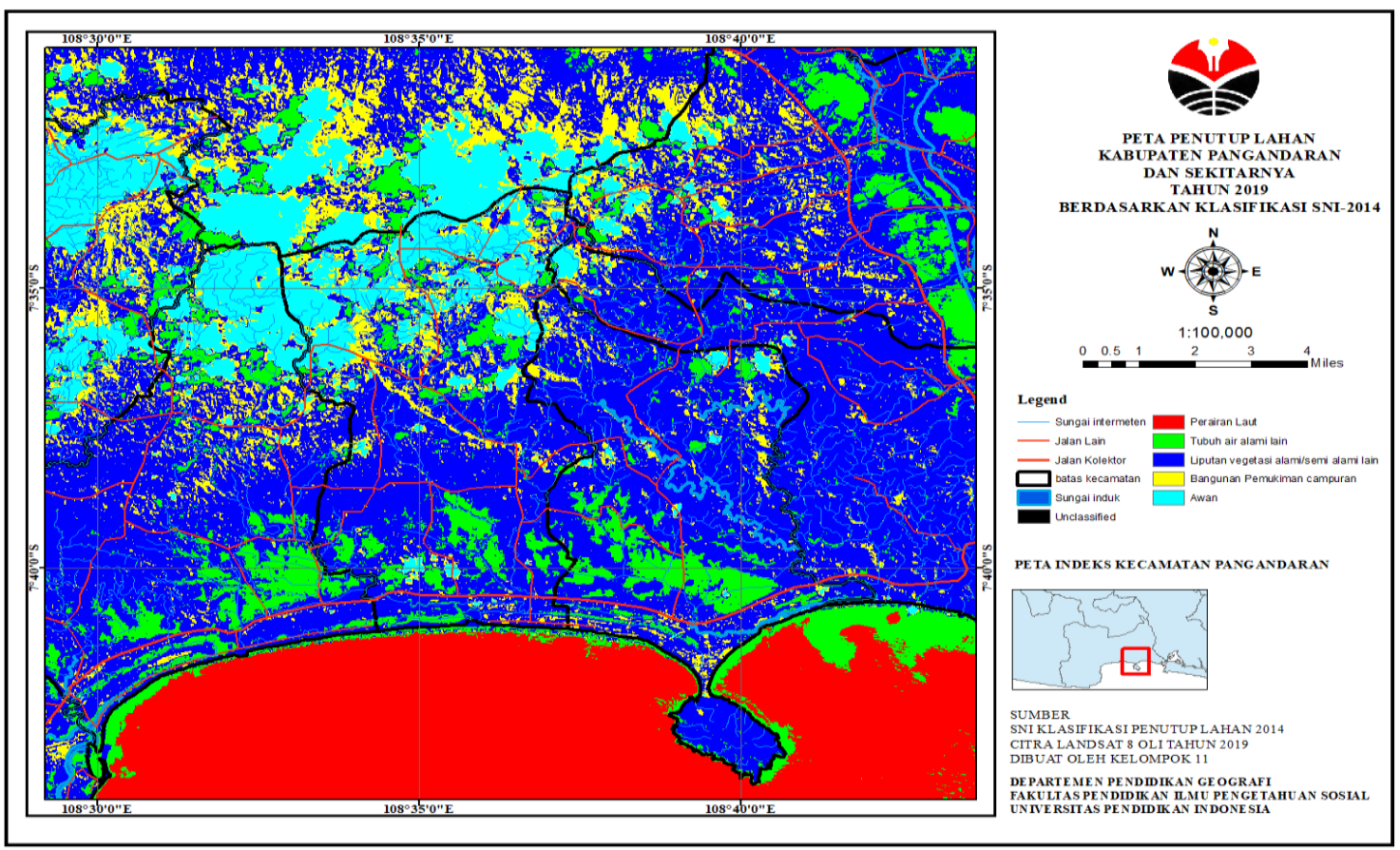

Gambar 4. Peta Penutup Lahan Kabupaten Pangandaran Tahun 2019 Berdasarkan Klasifikasi SNI2014 Menggunakan Metode Unsupervised classification K-Means.

Akurasi Klasifikasi Tutupan Lahan Akurasi klasifikasi dan kappa statistik dihitung atau diperkirakan berdasarkan sampel, matriks konfusi pada hasil klasifikasi data OLI menggunakan pengkelas IsoData dan K-Means. 


\begin{tabular}{|l|c|}
\hline Hasil interpretasi Tutupan lahan Berdasarkan SNI-2014 & Jumlah Sampel \\
\hline Liputan Vegetasi Alami/Semi alami lain & 15 \\
\hline
\end{tabular}

Tabel 2. Tabel Jumlah Sampel

\begin{tabular}{|c|c|c|c|c|}
\hline \multicolumn{5}{|c|}{ Hasil Interpretasi } \\
\hline \multirow{4}{*}{ 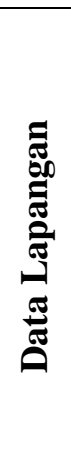 } & Obyek & $\begin{array}{l}\text { Liputan vegetasi } \\
\text { alami/semi alami } \\
\text { lain }\end{array}$ & $\begin{array}{l}\text { Bangunan } \\
\text { Pemukiman/campuran }\end{array}$ & Jumlah \\
\hline & $\begin{array}{l}\text { Liputan vegetasi } \\
\text { alami/semi } \\
\text { alami lain }\end{array}$ & 13 & $\mathbf{0}$ & 13 \\
\hline & $\begin{array}{l}\text { Bangunan } \\
\text { Pemukiman/cam } \\
\text { puran }\end{array}$ & 2 & $\mathbf{0}$ & 2 \\
\hline & Jumlah & 15 & $\mathbf{0}$ & 15 \\
\hline
\end{tabular}

Tabel 3. Matriks kesalahan (confusion matrix).

Berdasarkan tabel di atas, ketelitian seluruh kategori adalah :

$$
\text { Kappa }(k)=\frac{13}{15} x 100=86.67 \%
$$

United States Geological Survey (USGS) telah menetapkan tingkat ketelitian klasifikasi atau interpretasi minimum dengan menggunakan penginderaan jauh yaitu $85 \%$. Penelitiaan kali ini menghasilkan peta dengan ketelitian dengan nilai $86.67 \%$.

\section{Analisis Hasil Kelasifikasi Tutupan Lahan Berdasarkan Metode Unsupervised Classification IsoData dan K-Means}

Klasifikasi penggunaan lahan merupakan pengelompokan jenis-jenis penggunaan lahan ke dalam suatu kriteria atau jenis penggunaan lahan yang sama berdasarkan persamaan dalam sifatnya ataupun kaitannya antara objek-objek tersebut. Klasifikasi penggunaan lahan dilakukan dengan tujuan agar data dan informasi penggunaan lahan dapat lebih mudah dipahami. Klasifikasi penggunaan lahan akan didasarkan pada bentuk pemanfaatan dan penggunaan lahan kota, yaitu penggunaan lahan dalam kaitannya dengan pemanfaatan sebagai ruang pembangunan (Setiawan, 2019).

Apabila kita cermati kedua peta tutupan lahan diatas memiliki perbedaanperbedaan luas klasifikasi tutupan lahan, hal tersebut disebabkan karena ukuran objek dapat mengalami over segmentation atau under segmentation. Segmentasi yang menghasilkan ukuran poligon melebihi objek akan menyebabkan over segmentation sedangkan segmentasi yang menghasilkan ukuran poligon yang kurang dari ukuran objek pada citra akan menyebabkan under segmentation. Objek citra yang mengalami over segmentation atau under segmentation akan berpengaruh besar dalam pendefinisian objek sebagai kelas tutupan lahan (Maksum, 2016).

Segmentasi citra yang mengalami under segmentation berpeluang lebih besar kelas tutupan lahan tidak terklasifikasi dengan benar. Objek citra yang berukuran kecil dapat bergabung dengan objek lainnya sehingga dalam satu objek terdiri dari dua kelas tutupan lahan atau lebih menyebabkan algoritma klasifikasi menganggap satu objek tersebut menjadi satu kelas tutupan lahan. Sementara citra yang mengalami over segmentation juga 
dapat menyebabkan kesalahan klasifikasi karena objek yang terlalu banyak dapat menyebabkan klasifikasi menjadi kompleks namun objek-objek yang berukuran kecil dapat terklasifikasi dan masih berpeluang dapat terklasifikasi dengan benar. Oleh karena itu, ukuran poligon objek citra dari hasil segmentasi nantinya akan berpengaruh pada hasil klasifikasi tutupan lahan (Maksum, 2016).
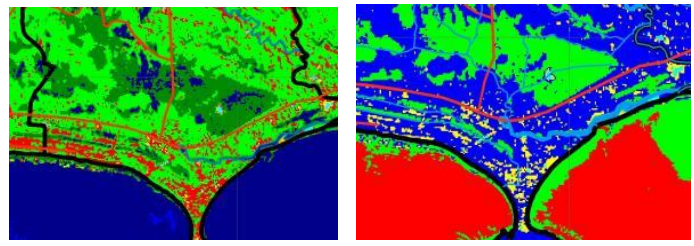

Gambar 5. Segmentasi yang Mengalami Over Segmentation (kiri) dan Under Segmentation (kanan).

Hal ini mungkin disebabkan karena nilai piksel dari area pada citra hampir sama atau bahkan sama dengan nilai piksel dari hutan. Hal tersebut sulit diantisipasi pada pembuatan training area, jika training area untuk perairan tidak dibuat maka perairan yang sebenarnya pada citra tidak dapat diklasifikasi (Yekti, 2013).

\section{Pemanfaatan Peta Tutupan Lahan untuk Perencanaan Wilayah dan Pembangunan}

Lahan selalu mengalami perubahan dari waktu ke waktu seiring meningkatnya kebutuhan manusia akan ruang. Perubahan pemanfaatan ruang ini disebabkan kebutuhan akan lahan non pertanian cenderung terus mengalami peningkatan, seiring pertumbuhan dan perkembangan suatu kawasan perkotaan, sehingga mengakibatkan penguasaan dan penggunaan lahan yang tak terkendali. Selain itu, perubahan fungsi pemanfaatan ruang juga biasanya terjadi dengan gejala "penetrasi" yaitu dengan penerobosan fungsi baru ke dalam suatu fungsi yang homogen, misalnya ketika masyarakat atau pengembang mengubah lahan pertanian atau permukiman menjadi fungsi komersial (Umar, 2016).

Remote Sensing (penginderaaan jauh) telah digunakan secara luas untuk berbagai keperluan, antara lain pertanian, biologi, pertambangan, kelautan, dan sebagainya. Penginderaan jauh merupakan suatu metode untuk memperoleh informasi tentang suatu objek, areal atau fenomena geografis melalui analisa data yang diperoleh dari sensor (Indarto, 2009).

Ilmu wilayah mempertimbangkan aspek ruang dan lingkungan selama berkaitan dengan aspek-aspek lokasi, desa, kota, atau wilayah. Salah satu konsepnya adalah setiap wilayah senantiasa memiliki karakteristik khas yang hanya ada pada wilayah tersebut, dan hal ini merupakan sebuah potensi yang sangat baik apabila mampu dimanfaatkan secara optimal. Dengan mengetahui berbagai informasi terkait suatu wilayah, maka siapa saja dapat melakukan perencanaan wilayah dan pembangunan yang dapat meningkatkan aktifitas ekonomi, industrialisasi, pariwisata kesehatan, pendidikan, dan lain-lain.

Kecamatan Pangandaran dilihat dari segi geografi desa kota merupakan daerah peralihan atau disebut dengan istilah periurban. Pada wilayah peri-urban, dimana merupakan wilayah yang berada di antara perkotaan dan pedesaan, wilayah ini mengalami perubahan bentuk pemanfaatan lahan yang dampaknya bisa berupa hilangnya lahan pertanian, adanya gejala komersialisasi dan intensifikasi lahan pertanian, sampai menurunnya produksi dan produktivitas pertanian (Yunus, 2008. Dalam Dewi, 2013).

Salah satu ciri khas daerah pangandaran adalah lingkungan fisik dan sosialnya yang sangat menunjang terhadap aktifitas pariwisata. Keindahan alam, sarana transportasi yang menunjang, akses yang mudah, serta masyarakatnya yang ramah, menjadikan pangandaran sebagai kawasan wisata favorit yang senantiasa didatangi wisatawan lokal maupun internasional. Komoditas khas pangandaran yang sangat terkenal adalah ikan asin jambal roti, kemudian liputan vegetasi yang sangat dominan adalah pohon kelapa, dan pohon pisang.

Perubahan pengunaan lahan dari vegetasi menjadi non-vegetasi, seperti hutan menjadi permukiman dapat merubah albedo dari jumlah sinar matahari yang dapat diserap oleh permukaan tanaman, selain itu juga menjadi salah satu penyebab perubahan iklim 
secara global (Hairiah et al. 2001. Dalam Prasetyo, 2010).

Dilihat dari kenampakan pada citra, pola pemukiman masyarakat kecamatan pangandaran adalah linear mengikuti garis pantai, hal ini menyebabkan daerah-daerah yang tidak berasosiasi dengan pantai cenderung dijadikan sebagai wilayah perkebunan, dan beberapa diantaranya dibiarkan sebagai hutan alami. Komoditas hasil pertanian yang sangat tinggi kuantitasnya adalah pisang dan kelapa, hal ini jelas merupakan suatu potensi yang dapat dimanfaatkan oleh para wirausahawan untuk mendirikan perusahaan-perusahaan yang memanfaatkan komoditas hasil pertanian atau bahkan memanfaatkan pangandaran sebagai tempat wisata yang senantiasa ramai pengunjung dengan mendirikan industri perhotelan dan tempat rumah makan.

Sebagai suatu bidang kajian, ilmu perencanaan dan pengembangan wilayah tergolong dalam keilmuan yang multidisiplin, meliputi bidang-bidang ilmu fisik, sosial, ekonomi, hingga manajemen ( Rustadi, 2018). Berdasarkan analisa tersebut, pemerintah dan masyarakat setempat dihadapkan pada kondisi yang menguntungkan secara ekonomi. Tetapi, apabila suatu daerah didatangi banyak pendatang maka beban tanggungan pemerintah pun semakin meningkat. Jika pembangunan sarana-prasarana dan infrastruktur tidak siap untuk melayani masyarakat lokal dan para wisatawan, maka daerah pangandaran akan mengalami kondisi yang tidak teratur dan tidak nyaman. Oleh karena itu kesadaran dari tiaptiap stakeholder yang berkepentingan dengan wilayah pangandaran harus menyiapkan berbagai perencanaan untuk menghindari dampak-dampak negatif yang dapat terjadi di balik potensi besar wilayah pangandaran ini.

Berdasarkan hasil kajian Badan Penelitian dan Pengembangan Pertanian (2007), yang utamanya didasarkan pada hasil pemetaan sumberdaya lahan tingkat tinjau, dari total daratan Indonesia seluas 188,2 juta ha, lahan yang berpotensi atau sesuai untuk pertanian seluas 94 juta ha, yaitu 25,4 juta ha untuk pertanian lahan basah (sawah) dan 68,6 juta ha untuk pertanian lahan kering (Tabel 2). Lahan basah adalah lahan-lahan yang secara biofisik sesuai untuk pengembangan lahan sawah, meliputi lahan sawah yang saat ini ada, lahan rawa, maupun lahan non rawa yang memungkinkan untuk digenangi atau diirigasi. Lahan basah yang sesuai untuk lahan sawah seluas 25,4 juta ha, terluas terdapat di Papua (7,4 juta ha), kemudian yang lainnya terdapat di Kalimantan Tengah (2,3 juta ha), Kalimantan Barat (1,8 juta ha), Jawa Tengah (1,6 juta ha), Jawa Timur (1,5 juta ha), Riau (1,1 juta ha), dan provinsi lainnya di bawah 1 juta ha. Tanpa mempertimbangkan RT/RW Kabupaten/Kota, lahan tersedia tersebut terdapat di kawasan budidaya pertanian atau di kawasan hutan. Pada kawasan pertanian, lahan tersedia dapat berupa padang alang-alang/rumput, semak belukar, dan hutan sekunder. Pada kawasan hutan, lahan tersedia berupa hutan konversi dan hutan produksi yang secara hukum jika dibutuhkan dan disepakati dapat dijadikan sebagai lahan pertanian (Hidayat, 2009).

Potensi suatu wilayah untuk pengembangan pertanian pada dasarnya ditentukan oleh sifat lingkungan fisik dan persyaratan penggunaan tertentu. Kecocokan antara sifat lingkungan fisik suatu wilayah dengan persyaratan penggunaan atau komoditas memberikan gambaran atau informasi bahwa lahan tersebut potensial untuk dikembangkan bagi tujuan tersebut. Maksudnya, lahan tersebut akan mampu memberikan hasil yang sesuai dengan yang diharapkan dengan tetap mempertimbangkan masukan (input) yang diperlukan (Tim Pusat Penelitian Tanah dan Agroklimat, 1993. Dalam lahan, 2008)

Indonesia merupakan salah satu negara berkembang yang sedang melaksanakan pembangunan di berbagai sektor. Seperti yang diketahui selama ini, pembangunan memberikan banyak sekali manfaat terutama penyediaan lapangan kerja bagi masyarakat, tetapi di samping itu pembangunan juga membutuhkan pengorbanan-pengorbanan lingkungan seperti perubahan tata guna lahan, dari semula merupakan ruang hijau menjadi gedung-gedung bertingkat atau permukiman, pertanian ataupun industri (Yuniarti, 2013).

Kegiatan pembangunan selain menghasilkan manfaat juga membawa risiko (dampak negatif) terhadap lingkungan. 
Manfaat dan risiko tersebut harus diperhitungkan secara seimbang. Dampak negatif harus dapat ditekan menjadi minimal atau jika mungkin dihilangkan sama sekali, sedangkan manfaat harus ditingkatkan agar kegiatan pembangunan berdampak optimal terhadap lingkungan bio-fisik, sosial dan ekonomi (Hidayat, 2009).

\section{SIMPULAN}

Berdasarkan nilai akurasi ketelitian yang cukup tinggi dan memenuhi syarat yang ditetapkan oleh USGS yang menyatakan ketelitian interpretasi lebih dari $85 \%$, sehingga hasil klasifikasi citra Landsat 8 di Kabupaten Pangandaran dapat digunakan untuk berbagai macam tujuan. Kelas-kelas penutup lahan yang terdapat pada wilayah penelitian berdasarkan citra adalah liputan vegetasi alami/semi alami lain, hutan mangrove, bangunan bukan pemukiman, dan bangunan pemukiman campuran. Manfaat spesifik peta hasil klasifikasi tutupan lahan tersebut adalah untuk analisis spasial dalam bidang perencanaan dan pengembangan wilayah atau pembangunan.

\section{REKOMENDASI}

Dilihat dari segi data luas wilayah tutupan lahan Kabupaten Pangandaran didominasi oleh liputan vegetasi alami/semi alami lain, saat groundchek diperoleh fakta bahwa jenis tanaman yang mendominasi adalah pohon kelapa yang tumbuh liar. Hal ini merupakan suatu potensi yang dapat dimanfaatkan oleh para wirausahawan untuk mengolahnya menjadi suatu komoditas yang khas dan bernilai ekonomis tinggi. Pemerintah dan masyarakat juga dapat leluasa melakukan pembangunan dan pengembangan kawasan wisata Pangandaran dengan melakukan alih pungsi lahan.

\section{UCAPAN TERIMA KASIH}

Terimakasih kepada yang terhormat Bapak Prof. Dr. H. Dede Sugandi, M.Si dan Bapak Riki Ridwana, S.Pd. M.Sc., selaku dosen yang membimbing penulis dalam penulisan artikel bertema penginderaan jauh ini, yang sangat bermanfaat. Begitu juga kepada mahasiswa
Pendidikan Geografi UPI angkatan 2018 yang telah bekerjasama dalam merancang penelitian ini.

\section{DAFTAR PUSTAKA}

Bode, C., Saroinsong, F. B., Tasirin, J. S., \& Rombang, J. A. (2015, July). ANALISIS PERUBAHAN TUTUPAN LAHAN DI TAMAN HUTAN RAYA GUNUNG TUMPA MENGGUNAKAN SISTEM INFORMASI GEOGRAFIS. In Cocos (Vol. 6, No. 11).

Dewi, N. K., \& Rudiarto, I. (2013). Identifikasi Alih Fungsi Lahan Pertanian dan Kondisi Sosial Ekonomi Masyarakat Daerah Pinggiran di Kecamatan Gunungpati Kota Semarang. Jurnal Wilayah dan Lingkungan, 1(2), 175-188.

Hayati, S. (2010, July). Partisipasi masyarakat dalam pengembangan ekowisata di Pangandaran-Jawa Barat. In Forum Geografi (Vol. 24, No. 1, pp. 12-27).

Hidayat, A. (2009). Sumberdaya lahan indonesia: potensi, permasalahan, dan strategi pemanfaatan. Jurnal Sumberdaya Lahan, 3(2).

Hidayat, M. (2011). Strategi Perencanaan Dan Pengembangan Objek Wisata (Studi Kasus Pantai Pangandaran Kabupaten Ciamis Jawa Barat). THE Journal: Tourism and Hospitality Essentials Journal, 1(1), 33-44.

Indarto, I., \& Faisol, A. (2009). IDENTIFIKASI DAN KLASIFIKASI PERUNTUKAN LAHAN MENGGUNAKAN CITRA ASTER (Landuse Identification and Classification Using ASTER Multispectral Data). Media Teknik Sipil, 9(1), 1-8.

Jaya, L. M. (2013). Analisis perubahan tutupan lahan di wilayah pesisir teluk kendari menggunakan citra satelit resolusi tinggi (kurun waktu 2003-2009).

Lahan, S. D. (2008). "PENENTUAN PEMANFAATAN LAHAN" Kajian Land Use Planning dalam Pem anfaatan Lahan Untuk Pertanian.

Maksum, Z. U., Prasetyo, Y., \& Haniah, H. (2016). Perbandingan Klasifikasi Tutupan Lahan Menggunakan Metode Klasifikasi Berbasis Objek Dan Klasifikasi Berbasis Piksel Pada Citra 
Resolusi Tinggi Dan Menengah. Jurnal Geodesi Undip, 5(2), 97-107.

Muttaqin, S., \& Aini, Q. (2011). Analisis perubahan penutup lahan hutan dan perkebunan di Provinsi Jambi Periode 2000-2008. STUDIA INFORMATIKA: JURNAL SISTEM INFORMASI, 4(2).

Pahleviannur, M. R. (2019). Pemanfaatan Informasi Geospasial Melalui Interpretasi Citra Digital Penginderaan Jauh untuk Monitoring Perubahan Penggunaan Lahan. JPIG (Jurnal Pendidikan dan Ilmu Geografi), 4(2), 1826.

Prasetyo, A. (2010). "Carbon Stock Changes Assessment in Tambling Wildlife Nature Conservation Bukit Barisan Selatan National Park".

Rustiadi, E. (2018). Perencanaan dan pengembangan wilayah. Yayasan Pustaka Obor Indonesia.

Sampurno, R. M., \& Thoriq, A. (2016). Klasifikasi Tutupan Lahan Menggunakan Citra Landsat 8 Operational Land Imager (Oli) Di Kabupaten Sumedang (Land Cover Classification Using Landsat 8 Operational Land Imager (Oli) Data In Sumedang Regency). Jurnal Teknotan $\mathrm{Vol}, 10(2)$.

Septiani, R., Citra, I. P. A., \& Nugraha, A. S. A. (2019). Perbandingan Metode Supervised Classification dan Unsupervised Classification terhadap
Penutup Lahan di Kabupaten Buleleng. Jurnal Geografi: Media Informasi Pengembangan dan Profesi Kegeografian, 16(2), 90-96.

Setiawan, A. K., \& Rahayu, S. (2018). Kajian Perubahan Penggunaan Lahan dan Kesesuaiannya Dengan Rencana Tata Ruang Wilayah (RTRW) Kabupaten Rejang Lebong Berbasis Sistem Informasi Geografis dan Penginderaan Jauh. Teknik PWK (Perencanaan Wilayah Kota), 7(3).

Umar, F. P., Sela, R. L., \& Tarore, R. C. (2016). Perubahan Fungsi Pemanfaatan Ruang di Kelurahan Mogolaing Kota Kotamobagu. SPASIAL, 3(3), 156-163.

Wibowo, L. A., Sholichin, M., Rispiningtati, R., \& Asmaranto, R. (2013). Penggunaan Citra Aster Dalam Identifikasi Peruntukan Lahan Pada Sub DAS Lesti (Kabupaten Malang). Jurnal Teknik Pengairan, 4(1), 39-46.

Yekti, A., Sudarsono, B., \& Subiyanto, S. (2013). Analisis perubahan tutupan lahan DAS Citanduy dengan metode penginderaan jauh. Jurnal Geodesi UNDIP, 2(4).

Yuniarti, F. (2013). Analisis Geospasial Perubahan Tata Guna Lahan terhadap Debit DAS Way Kuala Garuntang Bandar Lampung. Universitas Lampung, Lampung. 